\title{
EIF1B Gene
}

National Cancer Institute

\section{Source}

National Cancer Institute. EIF1B Gene. NCI Thesaurus. Code C118980.

This gene is involved in the initiation of protein translation. 